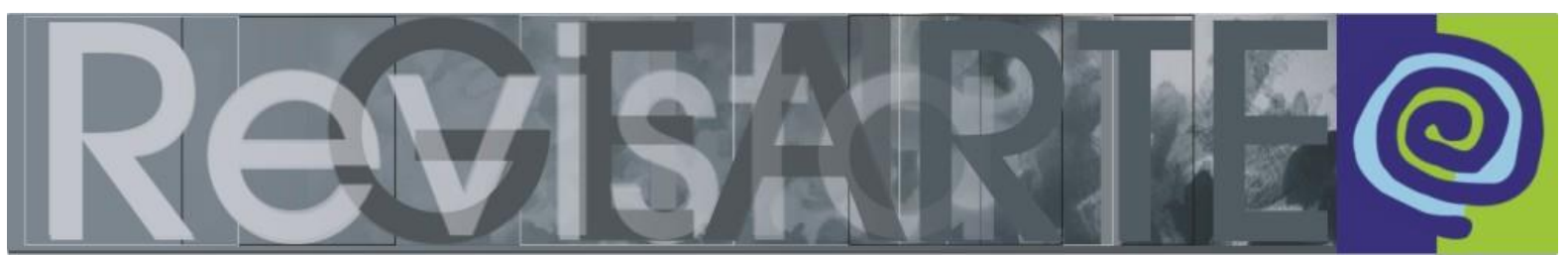

ISSN 2357-9854 | e-ISSN 2596-3198 (online)

\title{
Brincando com música em um curso de Pedagogia
}

\author{
Monique Traverzim (ic) \\ (Centro Universitário Campo Limpo Paulista - UNIFACCAMP, \\ Campo Limpo Paulista/SP, Brasil)
}

RESUMO - Brincando com música em um curso de Pedagogia - Este artigo apresenta um relato de experiência a respeito de um processo de musicalização desenvolvido no curso de Licenciatura em Pedagogia do Centro Universitário Campo Limpo Paulista. Trata-se de uma proposta de educação musical baseada no conceito de experiência de Jorge Larrosa Bondia, em que as estudantes têm a oportunidade de experienciar brincadeiras da cultura tradicional da infância e criar brincadeiras originais. Observou-se que, por meio do brincar, elas puderam reconhecer o potencial musical e criativo que carregam em si, ter contato com conteúdos musicais e refletir acerca dos modos de se trabalhar com música na Educação Infantil e Anos Iniciais do Ensino Fundamental. Espera-se que este relato, junto do repertório de brincadeiras, do referencial bibliográfico e fonográfico que ele traz, possa incentivar as pedagogas em formação e atuantes a desenvolverem trabalhos com música nas escolas de Educação Básica.

\section{PALAVRAS-CHAVE}

Musicalização. Educação musical. Formação musical de pedagogos. Arte na pedagogia e brincadeiras da cultura tradicional da infância.

\begin{abstract}
Playing with music in a Pedagogy course - This article presents an experience report about a musicalization process developed in the Licentiate Degree in Pedagogy at Centro Universitário Campo Limpo Paulista. It is a proposal for musical education based on Jorge Larrosa Bondia's concept of experience, in which students have the opportunity to experience traditional childhood culture games and create original games. It was observed that, through playing, they were able to recognize the musical and creative potential they carry within themselves, have contact with musical content and reflect on the ways of working with music in Preschool and Elementary School. It is hoped that this report, together with the repertoire of games, the bibliographic and phonographic references it brings, can encourage pedagogues in training and working to develop work with music in Basic Education schools.
\end{abstract}

\section{KEYWORDS}

Musicalization. Musical education. Musical education of pedagogues. Art in the pedagogy and games of traditional childhood culture.

RESUMEN - Jugando con la música en un curso de Pedagogía - Este artículo presenta un relato de experiencia sobre un proceso de musicalización desarrollado en la Licenciatura en Pedagogía del Centro Universitário Campo Limpo Paulista. Se trata de una propuesta de educación musical basada en el concepto de experiencia de Jorge Larrosa Bondia, en la que los alumnos tienen la oportunidad de experimentar juegos tradicionales de la cultura infantil y crear juegos originales. Se observó que, jugando, fueron capaces de reconocer el potencial musical y creativo que llevan dentro de sí mismos, tener contacto con contenidos musicales y reflexionar sobre las formas de trabajar con la música en Educación Infantil y en la Escuela Primaria. Se espera que este informe, junto con el repertorio de juegos, las referencias bibliográficas y fonográficas que aporta, pueda animar a los pedagogos en formación y activo para desarrollar el trabajo con la música en las escuelas de Educación Básica.

PALABRAS CLAVE

Musicalización. Educación musical. Educación musical de pedagogos. El arte en la pedagogía y los juegos de la cultura infantil tradicional. 


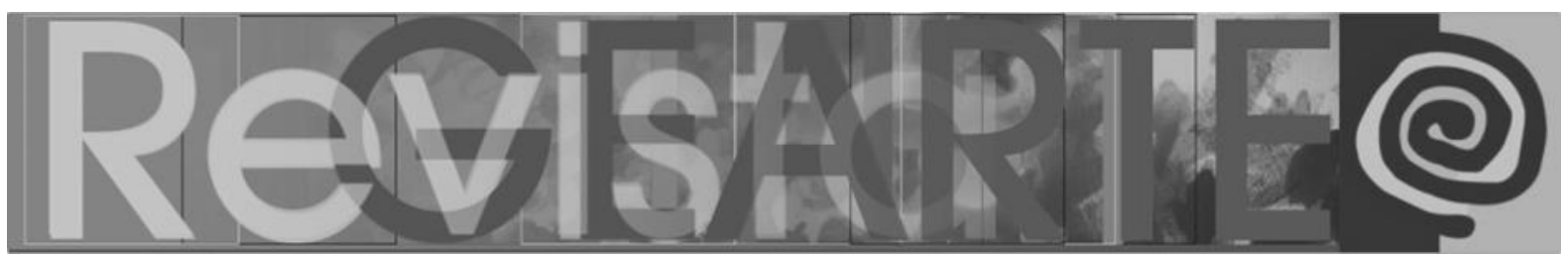

Dividir experiências a respeito de processos de ensino e aprendizagem em arte realizadas com alunas ${ }^{1}$ de pedagogia é sempre um privilégio, uma grande satisfação e alegria. Digo isso pelos desafios em encontrar um espaço dentro do currículo da graduação em Pedagogia, tanto por conta da compreensão e reconhecimento da necessidade da formação artística da pedagoga quanto pela grade curricular estar repleta de disciplinas.

Porém, não pretendo discutir aqui a respeito desses desafios, mas sim, partilhar das experiências com educação musical que vivencio em meu trabalho desde o ano de 2012, no Centro Universitário Campo Limpo Paulista (UNIFACCAMP), no curso de Licenciatura em Pedagogia.

A referida instituição de ensino superior está situada no interior do estado de São Paulo e faz parte da Aglomeração Urbana de Jundiaí, "unidade regional do Estado constituída pelo agrupamento dos Municípios de Cabreúva, Campo Limpo Paulista, Itupeva, Jarinu, Jundiaí, Louveira e Várzea Paulista" (SÃO PAULO, 2011)

Não temos, na UNIFACCAMP, uma disciplina específica para trabalhar com música. Foi por meio do convite de um dos coordenadores do curso de Licenciatura em Pedagogia, o prof. Dr. Fernando Roberto Campos que comecei a usufruir de algumas aulas ${ }^{2}$ da disciplina Cuidar, Educar e Brincar na Educação Infantil onde brincamos com música em sala de aula.

O professor Fernando é sociólogo, Mestre e Doutor em Educação, tem um olhar especialmente humano e democrático para a infância, bem como para a formação de educadores no que diz respeito ao acesso ao conhecimento e o desenvolvimento pleno de indivíduos críticos, atuantes na sociedade em que vivem. Ao iniciar esse texto, senti a necessidade de contatar o professor e pedir que ele me dissesse novamente a razão do convite para atuar na disciplina, a fim de que eu pudesse explicar adequadamente o motivo de eu estar no curso de Pedagogia, em uma disciplina que não é da área de Arte. Então ele, gentilmente, escreveu o seguinte texto: 


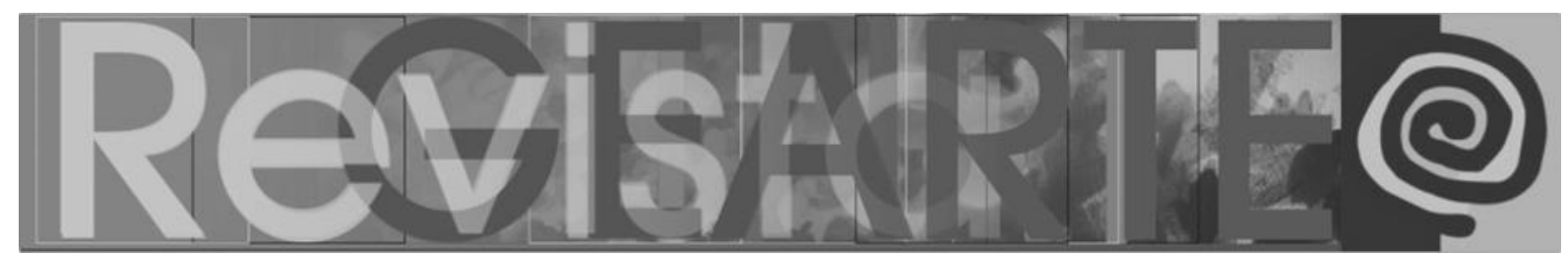

O convite para a profa. Monique lecionar a disciplina Cuidar e Educar na Educação foi seletivo, devido a sua formação teórica e experiência prática na área da educação musical.

A proposta era que a disciplina [Cuidar, Educar e Brincar na Educação Infantil], obrigatória no currículo do Curso de Pedagogia da UNIFACCAMP, fosse conduzida por dois professores. Um deles seria responsável pela discussão dos aspectos históricos e legais que envolvem o tema do cuidar e do brincar na educação infantil. $E$ outro professor para abordar a importância do ensino de artes e, particularmente da música na educação infantil. A ideia era um professor que não só fizesse esta discussão apenas no campo teórico, mas também que cuidasse desta formação musical dos próprios alunos do curso de Pedagogia, futuros professores da educação infantil.

A partir desse cuidado do professor coordenador do curso, passei a ter a responsabilidade de cuidar da formação musical das pedagogas no contexto de uma disciplina que trata da dicotomia entre o cuidar e o educar na Educação Infantil. Tema ainda muito discutido, mas que pouco tem sido colocado em prática na docência. De acordo com Heloisa H. de Azevedo (2013),

[...] no âmbito da formação dos professores, através da ação formativa desenvolvida pelos formadores, temos as possibilidades de contribuir para a superação desse problema da separação entre cuidado e educação, pois falar que na Educação Infantil, é 'necessário integrar cuidado e educação' é frase desgastada e que, até hoje, só mascarou tal problema, só alcançando o discurso e não a prática docente. (AZEVEDO, 2013, p. 102)

cuidar é intrínseco do educar na Educação Infantil, ele não se restringe aos cuidados com os aspectos biológicos do corpo, mas sim, se amplia para atender às necessidades da criança, disponibilizar a ela o acesso ao conhecimento e ajudá-la a se desenvolver plenamente. Posso me arriscar a dizer que essa dicotomia entre o cuidar e o educar é superada, na disciplina oferecida no curso de Pedagogia da UNIFACCAMP, com a inclusão do brincar, uma vez que a brincadeira traz conhecimentos a respeito de si próprio - de suas habilidades físicas, emocionais e afetivas -, conhecimentos a respeito do outro e a respeito do mundo que o circunda.

Assim, é justamente nesse espaço do brincar, que entra o trabalho com música - a partir do brincar, fomos juntas descobrindo o que tinha de música nas Parlendas, Quadrinhas, Fórmulas de Escolha, Jogos de Mãos, Brincadeiras de 


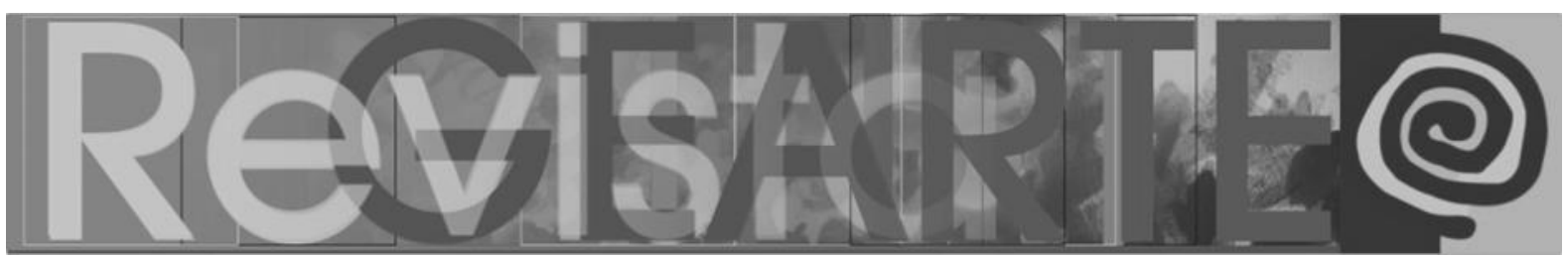

Roda, Rodas com Nome, somente para citar alguns exemplos de brincadeiras da cultura. As palavras a seguir desenvolvem essa problemática:

\begin{abstract}
Os profissionais da educação necessitam de momentos dedicados a eles próprios, momentos de contato humano em que possam enriquecer-se como pessoas, nutrir-se de sentimentos positivos que vão transmitir às crianças a seu cuidado. Ser capaz de comunicar um estado nascente de alegria e harmonia devia ser a prioridade profissional na vida quotidiana da atividade educativa (RODRIGUES; RODRIGUES, 2014, p. 287).
\end{abstract}

Ao brincarmos em sala de aula, brincamos juntas, nos reunindo em pares, pequenos grupos e grandes rodas. Tocamo-nos ao darmos as mãos, ao batermos nossas mãos com as mãos das parceiras, ao partilharmos materiais, sensações e ideias, ao nos olharmos, ao nos tocarmos, percebemo-nos e percebemos o outro.

Por meio do con[tato], ato de tocar o outro, de tocar-se, permitir ser tocado, tocar por meio do som, ser tocado pelo som, ato de inter[agir] com o outro, consigo mesmo e com o sonoro, tenho pensado e brincado com música junto das estudantes do curso de Pedagogia. Ao experienciarmos o con[tato], no grupo, por meio das brincadeiras da cultura tradicional da infância - brincadeiras novas e brincadeiras compartilhadas de nossas infâncias -, experimentamos, compartilhamos e construímos, juntas, um processo de musicalização.

Essas brincadeiras eram levadas por mim e, consequentemente, outras surgiam do repertório lúdico da infância das alunas ou do repertório que algumas delas tinham feito com seus filhos. Notei que brincadeiras cantadas e canções da cultura tradicional infantil apareciam em menor quantidade no repertório delas, pois, na maioria das vezes o repertório era falado, ou seja, rítmico. Apareciam poucas com melodia ${ }^{3}$ e quando eram apresentadas pelas alunas, era um repertório que elas tinham contato no estágio curricular supervisionado, no contexto escolar. Esse cenário exposto mostra a falta que a educação musical faz na vida escolar, em especial, nas escolas de educação básica e nos cursos de Pedagogia que formam o profissional que estará com as crianças desde a creche até o quinto ano do Ensino Fundamental, por pelo menos quatro horas diárias, durante cinco dias da semana. 


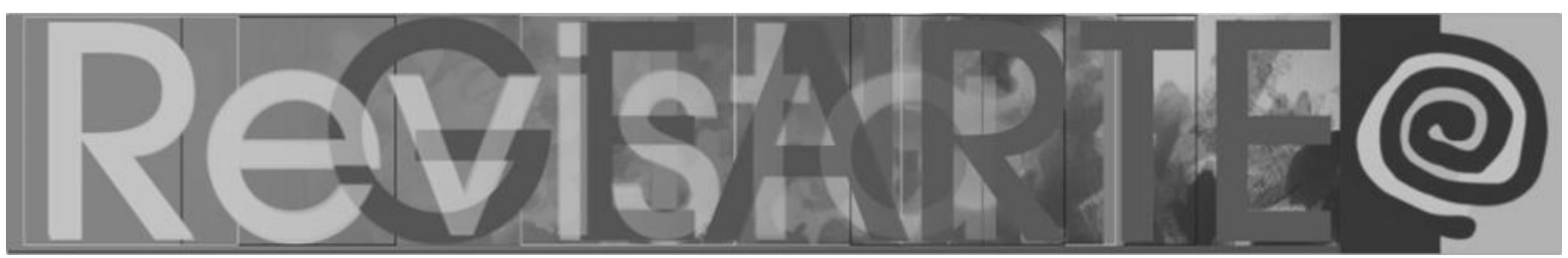

Pude notar, também, que esse repertório era pautado em materiais produzidos pela indústria cultural ${ }^{4}$ para o público infantil, sendo sempre as mesmas músicas - como Borboletinha e Cabeça, ombro, joelho e pé - somente para citar alguns exemplos. Esses materiais que as meninas faziam uso eram vídeos e áudios com pouca qualidade musical e que determinavam o repertório de gestos e movimentos corporais que a criança deveria fazer.

Ressalto que não há qualquer problema com o repertório supracitado, mas me preocupo com a forma que ele é utilizado e com o fato de ele ser material de referência para o trabalho com música, em especial, nas escolas de Educação Infantil. Ao comentar a respeito da qualidade musical, refiro-me a algumas questões como: o timbre da voz do(a) cantor(a) que as crianças vão ouvir e terão como referência, além da tessitura ${ }^{5}$ vocal que nem sempre está adequada à extensão da voz infantil - o que pode machucar as pregas vocais.

\begin{abstract}
Atualmente, as crianças cantam cada vez menos e sem qualquer preparação. O prazer de cantar é constantemente substituído pela televisão, vídeo, CDs e outros meios. Assistimos também ao desaparecimento progressivo das canções populares tradicionais, nos Jardins de Infância e [Anos Iniciais do Ensino Fundamental]. A voz é relegada para segundo plano. O que se passa hoje é preocupante. Há um aumento crescente das perturbações vocais que vão desde a rouquidão aguda ou crónica à completa e frequente afonia com graves reflexos na vida da criança. (GIGA, 2004, p. 69-70)
\end{abstract}

Tendo em vista essa realidade, procuro levar a atenção das alunas ao timbre de voz das crianças, como meninos e meninas falam todos de forma parecida e com um som mais agudo que a voz do adulto. Entretanto, respeito a tessitura vocal das alunas, por isso, procuramos cantar em uma altura que seja confortável para as vozes delas, de modo que elas possam trabalhar com as crianças adequadamente. A nota mais grave que utilizamos é o Lá2 e tentamos chegar até o Do4.

Figura 1 - Exemplo em partitura do Lá2 e Dó4

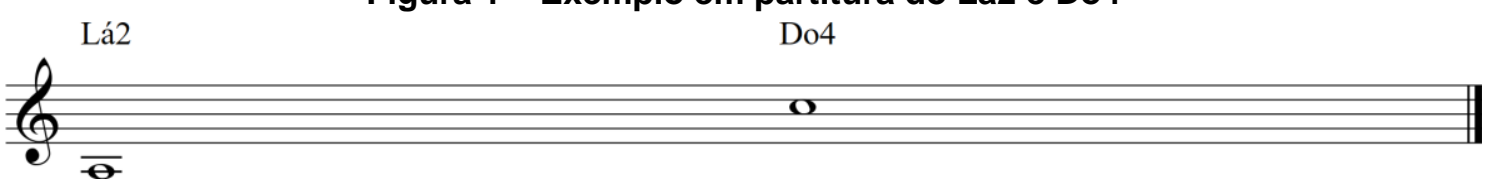

Fonte: Elaborado pela autora (2021). 


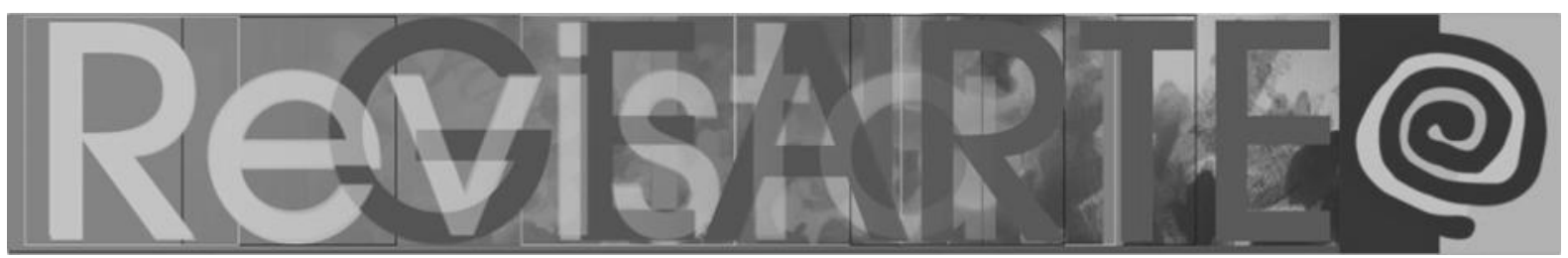

Existe muita divergência entre pesquisadores e educadores musicais no que diz respeito à extensão ${ }^{6}$ da voz infantil. Para se ter uma ideia, Young (apud SOBREIRA; BOECHAT, 2015), sugere que as canções utilizadas no jardim de infância contenham a extensão entre Lá 2 e Fá\#3; Chevais (apud GAINZA, 2009) descreve a extensão vocal infantil de modo progressivo de acordo com a idade: ele coloca a distância entre Lá2 e Mi3 para os quatro anos de idade e da nota Lá2 até Fá3 para os cinco anos de idade; Gordon (2000), afirma que no primeiro momento em que uma criança ou um bebê é colocado em contato com a música vocal, esta não deve ter nota mais grave que o Ré2 e, raramente, deverá ter nota mais aguda que Lá3.

Gainza (2009, p. 116) diz que "não é fácil e nem se quer possível fixar limites precisos à voz infantil em cada idade". Tanto o ambiente quanto a educação da criança vão influenciar no desenvolvimento de sua tessitura vocal. Alguns pesquisadores, como Gordon e Apostoli (2004), afirmam que:

\begin{abstract}
A exposição precoce à música contribui para o desenvolvimento da aptidão musical na criança. É por isso que a qualidade do ambiente em que as crianças são cuidadas e educadas em seus primeiros anos de vida são extremamente importantes. O que importa não é quantidade de estímulo musical, mas sim a qualidade, que é determinada pelas características das músicas que as crianças escutam e, não menos importante, os tipos de música que elas são expostas. (GORDON; APOSTOLI, 2004, p. 3, tradução nossa ${ }^{7}$ )
\end{abstract}

O arranjo musical é uma outra inquietação a respeito dessas referências musicais produzidas pela indústria cultural, uma vez que podem privar o contato do ouvinte com o timbre ${ }^{8}$ de instrumentos musicais acústicos e variados, sendo que algumas gravações são feitas com o uso de sons produzidos por meios eletrônicos, distantes do som real de um instrumento musical. Esclareço que, atualmente, existem duas formas de se manipular o som, uma em que se cria sons de modo a sintetizá-lo, o que muitas vezes o torna distante do timbre real deste instrumento e outra, por meio de Sampler, em que se grava o som real do instrumento musical para poder ser usado eletronicamente em gravações. 


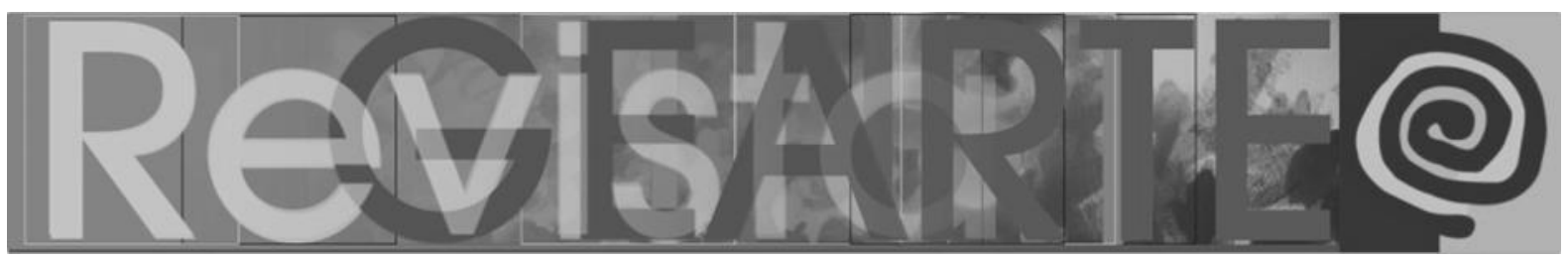

Outra preocupação diz respeito à limitação ao desenvolvimento do potencial criativo das crianças e de seus educadores, visto que esse tipo de material vem pronto, ou seja, com os modos de brincar, os gestos e os movimentos já estabelecidos. Dessa forma, resta pouco espaço para a pedagoga observar as necessidades, interesses e possibilidades de seus alunos, de modo a propiciar o pleno desenvolvimento deles.

A partir do exposto, reitero a necessidade de que as alunas da Pedagogia tenham a oportunidade de experienciar, tanto esse repertório que elas já conhecem e utilizam, como também, novos repertórios de brincadeiras da cultura tradicional infantil brasileira, de diferentes culturas e brincadeiras originais criadas por elas. Dessa maneira, elas poderão perceber e saber o que podem usufruir desses repertórios, de modo a desenvolverem habilidades musicais para produzirem e organizarem seus próprios materiais de musicalização.

As questões expostas a respeito da qualidade musical das canções e das brincadeiras disponíveis em gravações de áudio e vídeo são discutidas com as pedagogas no decorrer das aulas, por meio da escuta de diferentes materiais, da experiência em um processo de musicalização por meio das brincadeiras da cultura tradicional da infância e leitura de textos para fundamentar e esclarecer os conteúdos estudados. Um material que tem servido de base para essas discussões, bem como para a compreensão de conceitos dos elementos constitutivos da música e conhecimento de práticas pedagógico-musicais na educação infantil, é o livro Música na educação infantil: propostas para a formação integral da criança (BRITO, 2003). Esse é um material acessível às pedagogas e estudantes de pedagogia, no que diz respeito à linguagem, conteúdo, exemplos de atividades, organização e aquisição.

Anteriormente a essas experiências no curso de Pedagogia, estive em contato com a formação de pedagogas, na Pós-graduação em Educação Musical, também, na UNIFACCAMP. A união dessas experiências anteriores e aquela que se iniciava no ano de 2012, especificamente no curso de Pedagogia, trouxeram- 


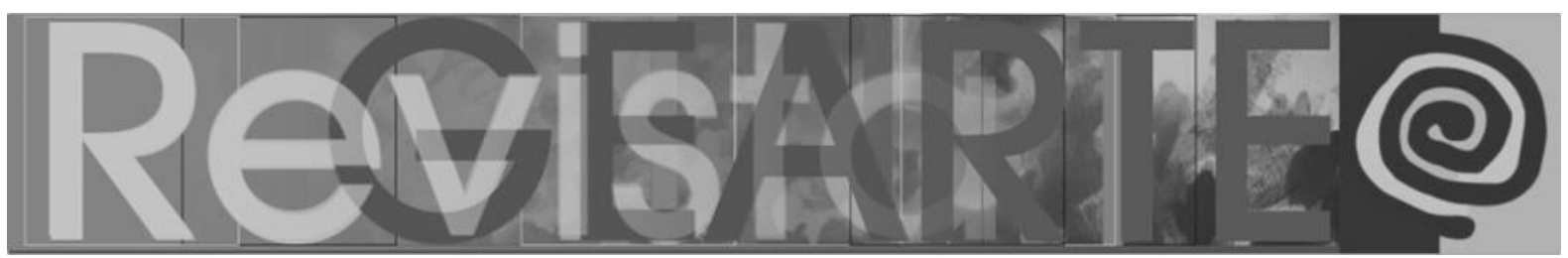

me um grande interesse em mergulhar na formação musical da professora de classe. Foi quando tive o desejo de fazer o Mestrado na área e, no mesmo ano, tive o privilégio de entrar em contato com o GPAP (Grupo de Pesquisa Arte na

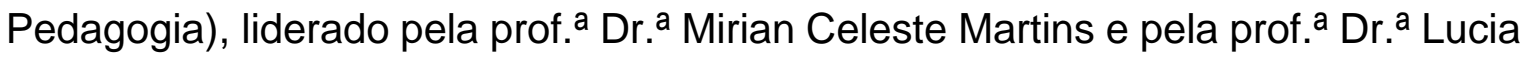
Maria Salgado dos Santos Lombardi e pude, então, mergulhar nas águas inquietas e férteis da pedagogia da qual tem nascido muita arte.

No ano de 2015, defendi a dissertação intitulada $A$ brincadeira da cultura tradicional da infância na formação musical do pedagogo (TRAVERZIM, 2015), no Instituto de Artes da Universidade Estadual Paulista "Júlio de Mesquita Filho" -

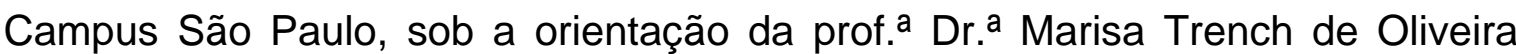
Fonterrada. Desde então, as brincadeiras da cultura da infância têm norteado meu trabalho com música no curso de Pedagogia, em especial, na disciplina Cuidar, Educar e Brincar na Educação Infantil.

\title{
As aulas de musicalização
}

\begin{abstract}
Em um primeiro momento, cursando a disciplina Cuidar, Educar e Brincar com o enfoque em musicalização tive a sensação de estar somente criando um repertório musical de canções para as crianças para posteriormente poder atuar, entretanto, foi muito além dessa simplória concepção. Música é emoção, é movimento, é prazer, é alegria e todos esses elementos estiveram sempre presentes em nossas aulas, bastava olhar para o lado para poder enxergar a criança que havia e que ainda há dentro de todos nós. Atuo como professora e sempre procurei adaptar algumas atividades para a faixa etária que trabalhava e o resultado foi muito satisfatório! Aquele momento prazeroso das aulas se multiplicou e pospôs fronteiras além da sala de aula. Com toda a certeza posso afirmar que a musicalização foi essencial em minha formação, pois despertou em mim o olhar que musicalizar faz parte da nossa história! (informação verbal) $)^{9}$
\end{abstract}

As palavras de Lívia, acima, conseguem resumir o que eu observava em todas as aulas. Em um primeiro momento, olhares desconfiados que, depois, se transformavam em olhares curiosos, gestos e movimentos tímidos, descrença no valor de uma aula prática e, ao mesmo tempo, alegria e euforia em brincar. Essa cena foi transmudada em episódios de confiança, descobertas, alegria, satisfação, respeito, união, prazer, segurança, trocas, saberes e muita arte. De modo que, ao 


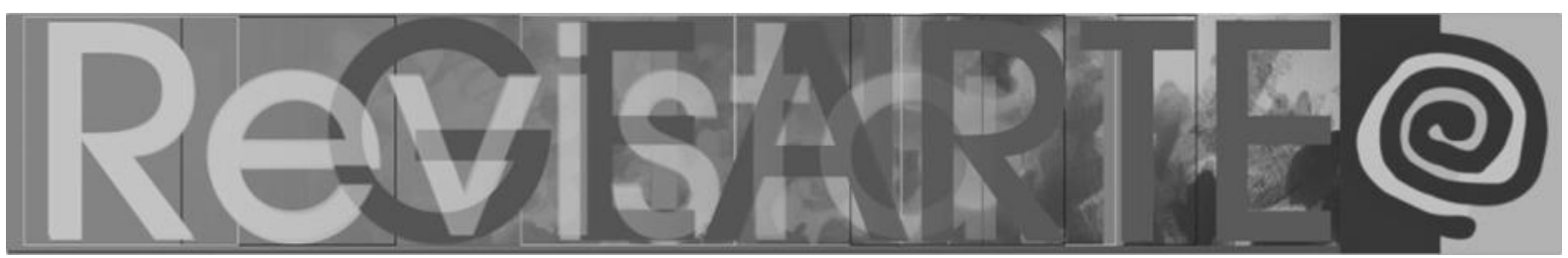

se permitirem experienciar as brincadeiras infantis, as alunas entravam em contato com o fato sonoro, com seu potencial musical e criativo desconhecido, por boa parte delas, e juntas fizemos arte em seus mais diversos sentidos:

1. Capacidade que tem o ser humano de pôr em prática uma ideia, valendo-se da faculdade de dominar a matéria [...]; 2. A utilização de tal capacidade, com vistas a um resultado que pode ser obtido por meios diferentes [...]; 3. Atividade que supõe a criação de sensações ou de estados de espírito de caráter estético, carregados de vivência pessoal e profunda, podendo suscitar em outrem o desejo de prolongamento ou renovação [...]; 4. Capacidade natural ou adquirida de pôr em prática os meios necessários para obter um resultado [...]; 5. Traquinada, travessura. (FERREIRA, 2008, n.p)

A partir da vivência das brincadeiras da cultura tradicional da infância, as futuras pedagogas iam conhecendo elementos constituintes da música e descobrindo quanta música elas sabiam e já faziam - sem perceber! Com o repertório aprendido, foram criados arranjos musicais com instrumentos de pequena percussão, objetos sonoros/instrumentos musicais, jogos de mãos e jogos de copos.

A música está presente na vida de praticamente todos os humanos. Contribui para a consciência de nós próprios e dos outros, para o desenvolvimento emocional, intelectual e social. Tem o poder de induzir emoções e sentimentos complexos como empowerment, realização, satisfação e bemestar. É expressão, comunicação e transcendência, e um poderoso elicitador do sentimento de ligação, de ser parte de um grupo, tem o poder de reabilitar e ajudar a construir ambientes onde 0 afeto pode crescer. Evidentemente, há outros fatores que a música <<seja >> ou <<possa ser >>. Portanto, não podemos falar de música ou de músicas sem pensar em todo o contexto de sua produção e recepção. Não existe música sem sujeito. (RODRIGUES; RODRIGUES, 2014, p. 22)

Lembro-me como se fosse hoje, da aluna Viviane ${ }^{10}$ me procurar ao final da aula, com um lindo sorriso no rosto, para me dizer que a sua turma, até o momento da musicalização, não havia trabalhado em conjunto. Era a primeira vez que elas tinham con[tato] umas com as outras e produziam juntas com um detalhe que me tocou: ela relatou que era primeira vez que todos sorriam! Portanto, extrapolamos o desenvolvimento de habilidades e competências musicais e chegamos a aspectos do desenvolvimento humano. 


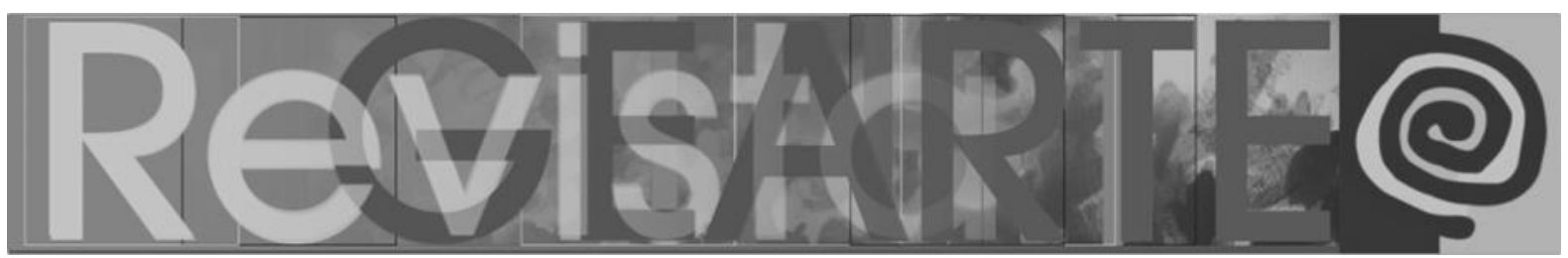

Digo chegamos porque me incluo no processo de ensino e aprendizagem em consonância com o pensamento do compositor e educador musical Murray Schafer (1991, p. 278) o qual afirma que "[...] uma aula deve ser uma hora de mil descobertas. Para que isso aconteça, professor e aluno devem em primeiro lugar, descobrirem-se um ao outro", (SCHAFER, 1991, p. 278). Além do preceito exposto, considero-me como um dos sujeitos dessa experiência que estou dividindo por meio deste relato.

\begin{abstract}
O sujeito da experiência é um sujeito 'ex-posto'. Do ponto de vista da experiência, o importante não é nem a posição (nossa maneira de pormos), nem a 'o-posição' (nossa maneira de opormos), nem a 'imposição' (nossa maneira de impormos), nem a 'proposição' (nossa maneira de propormos), mas a 'exposição', nossa maneira de 'expormos', com tudo o que isso tem de vulnerabilidade e de risco. Por isso é incapaz de experiência aquele que se põe, ou se opõe, ou se impõe, ou se propõe, mas não se 'ex-põe'. É incapaz de experiência aquele a quem nada the passa, a quem nada the acontece, a quem nada lhe sucede, a quem nada o toca, nada lhe chega, nada o afeta, a quem nada o ameaça, a quem nada ocorre. (LARROSA BONDIA, 2002, p. 24-25)
\end{abstract}

Esclareço que as práticas em educação musical que irei partilhar aqui estão fundamentadas nessa ideia de experiência de Jorge Larrosa Bondia (2002), que a define como algo que nos toque ou nos aconteça e que demanda um gesto de interrupção quase impossível de ser conquistado nos tempos atuais. Para o autor supracitado, a experiência requer parar,

[...] parar para pensar, parar para olhar, parar para escutar, pensar mais devagar, olhar mais devagar, e escutar mais devagar; parar para sentir, sentir mais devagar, demorar-se nos detalhes, suspender a opinião, suspender o juízo, suspender a vontade, suspender o automatismo da ação, cultivar a atenção e a delicadeza, abrir os olhos e os ouvidos, falar sobre o que nos acontece, aprender a lentidão, escutar aos outros, cultivar a arte do encontro, calar muito, ter paciência e dar-se tempo e espaço. (LARROSA BONDIA, 2002, p. 24)

Nessa experiência de musicalizar-se ao brincar, os licenciandos em pedagogia estão a aprender a respeito da música, do brincar, de si próprios, do outro, da cultura do povo que criou aquela brincadeira, como também, do seu futuro aluno. Prática e teoria caminham juntas, em constante diálogo reflexivo, a partir da premissa que "[...] a prática não é mera aplicação de conhecimentos, tampouco a 


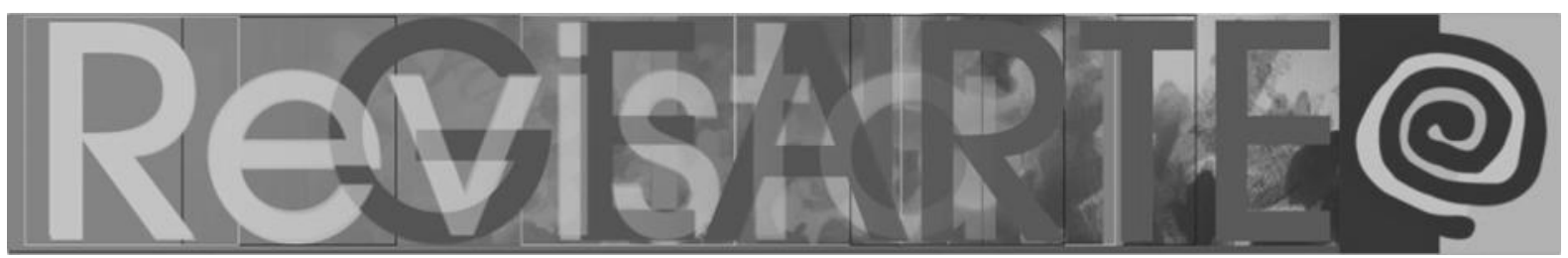

teoria em si melhora o mundo e as relações. Pelo contrário, há um risco constante de alienação da prática quando despregada do movimento de ida e vinda de uma à outra" (CASTANHO, 2019, p. 272).

Esse ir e vir entre prática e teoria é constante na práxis pedagógica, em especial, no contexto da educação infantil. Nessa fase da vida escolar, a criança aprende por meio da exploração, da experiência, da imitação na relação consigo mesmo e com o próximo, portanto, considero pertinente que o processo formativo da estudante de pedagogia possa se aproximar da realidade que ela irá vivenciar na sua futura vida profissional. Destarte, penso as brincadeiras tradicionais infantis como uma porta de entrada para o universo musical, por elas se constituírem como

[...] um tipo de alimento auditivo-espiritual completo, denso, mas ao mesmo tempo inócuo como o leite materno, capaz de preparar o ouvido e toda a sensibilidade para futuras aquisições e para uma etapa de maturidade. [...] Do mesmo modo que o leite materno, a presença de materiais folclóricos ${ }^{11}$ musicais na educação atenuará 0 efeito contraproducente de outros materiais mais pobres e inadequados. (GAINZA, 2010, p. 32, tradução nossa ${ }^{12}$ )

De acordo com a educadora musical argentina, citada anteriormente, a música da cultura tradicional infantil é de fácil assimilação por ser simples e compreensível. Ele atrai os ouvidos pela ingenuidade jocosa de seus textos e seu ritmo pitoresco,

[...] move elementos primitivos básicos, sobretudo em relação ao corporal e afetivo, o qual o aproxima ao homem sensível e, portanto, às crianças. Do ponto de vista musical, desenvolve-se sobre elementos claramente delimitados que constituem seu sistema melódico, harmônico e rítmico. A causa de sua simplicidade resulta em um veículo apto para a expressão de sentimentos e ideias elementares concretas. (GAINZA, 2010, p. 32 , tradução nossa ${ }^{13}$ )

Além disso, o contato com as brincadeiras infantis tradicionais possibilita a ampliação do repertório musical e o fortalecimento da segurança das pedagogas para desenvolverem trabalhos com música na escola de educação básica. A necessidade de ampliação do repertório musical e a insegurança para trabalhar com música foram percebidas ao longo dos anos no trabalho de musicalização no 


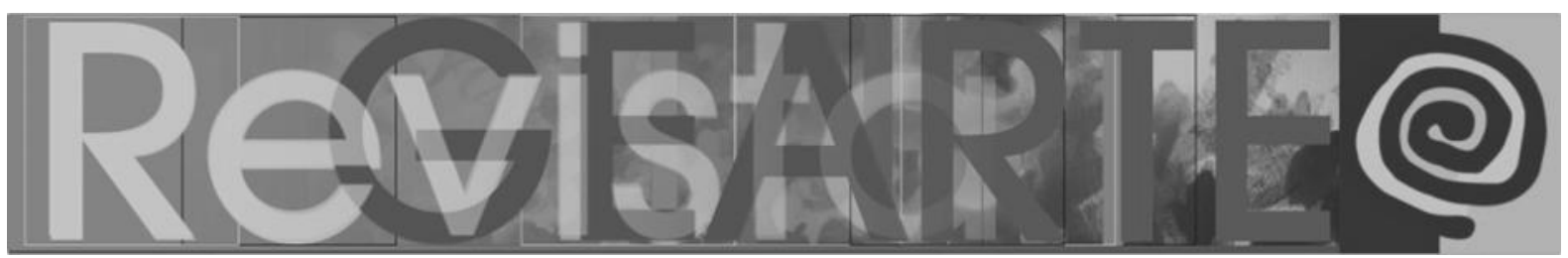

curso de Pedagogia da UNIFACCAMP, como também, no desenvolvimento da pesquisa de Mestrado com pedagogas formadas, quando pude observar que o maior envolvimento das pedagogas, dentre todas as atividades realizadas, deu-se com as brincadeiras da cultura tradicional da infância.

\begin{abstract}
Foi possível perceber, ao longo das práticas e diálogos realizados com os professores, a grande necessidade que tinham de obter materiais para trabalharem com Música na escola. Eles não só queriam o repertório, mas, também, desejavam se apropriar dele. Muitas vezes, os professores aproveitavam as novas aquisições de brincadeiras com seus alunos, na mesma semana que aprendiam. Isso mostra a relevância de se pesquisar a respeito da formação musical do pedagogo, pois eles requerem saber por onde começar, como fazer e saber fazer música com crianças de Educação Infantil e dos Anos Iniciais do Ensino Fundamental. (TRAVERZIM, 2015, p. 131-132)
\end{abstract}

A educadora musical e pesquisadora Aruna Correa (2014) reforça essas questões ao dizer que, em sua pesquisa de Mestrado, pôde perceber que quanto mais as alunas do curso de Pedagogia da Universidade Federal de Santa Maria/RS vivenciaram as oficinas de música, "mais alternativas e seguranças para trabalhar com música tiveram quando em exercício profissional na sua prática docente" (CORREA, 2014, p. 185).

\title{
As brincadeiras no processo de musicalização
}

Procuro começar o processo de musicalização com a canção da cultura infantil brasileira Borboletinha que, até o momento, tem sido a mais popular entre as alunas da Pedagogia. 


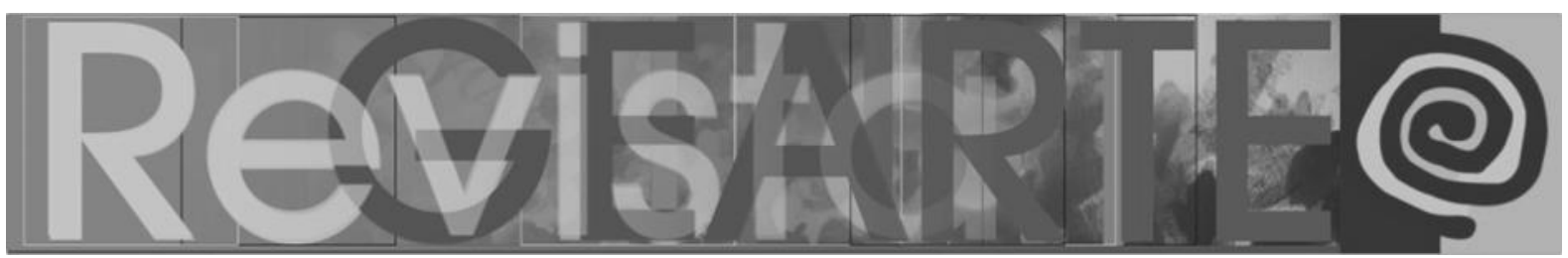

Figura 2 - Borboletinha

Borboletinha

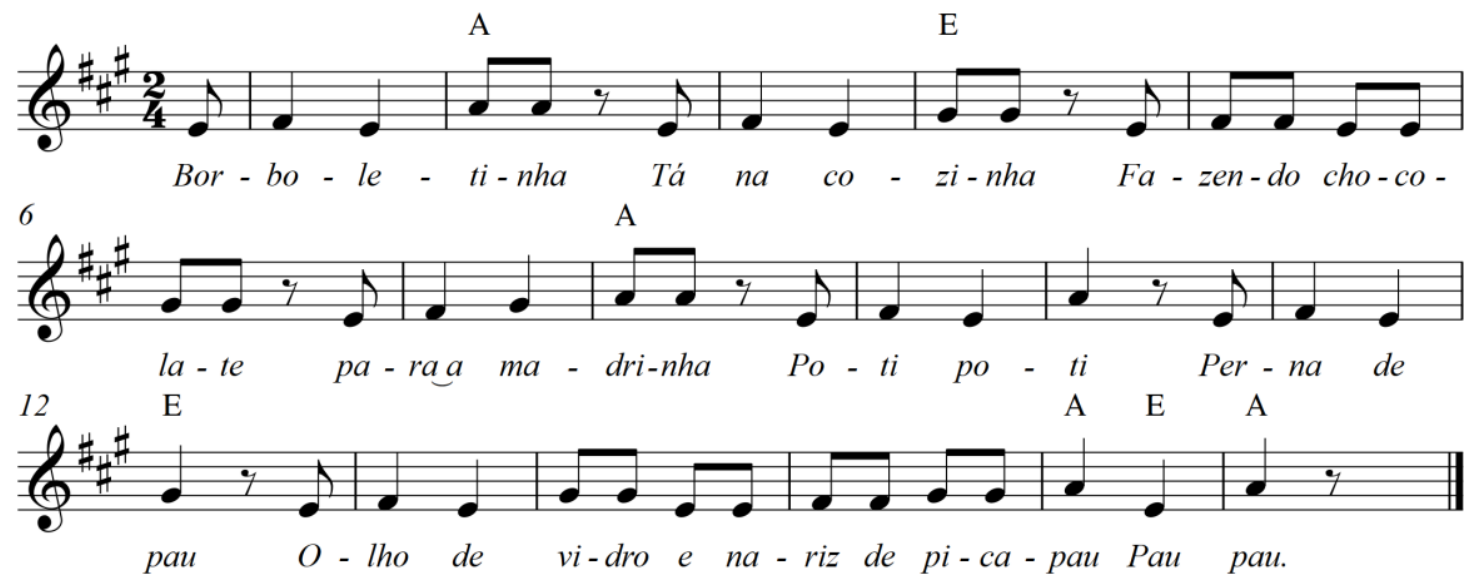

Editoração: Monique Traverzim

Fonte: Elaborado pela autora (2021).

Ao invés de somente cantarmos a canção, faço como um jogo de mãos que:

[...] está registrado no CD Abre a roda tin dô lê lê, um trabalho documental e de recriação da pesquisadora Lydia Hortélio. Enquanto se canta a canção, bate-se palmas nas coxas, palma consigo mesmo, palma com a outra pessoa em frente e segue-se a sequência de movimentos: palma consigo mesmo, palma nas coxas... 'No final cada uma tenta tocar o nariz da outra'. (HORTÉLIO, [200-] apud TRAVERZIM, 2015, p. 113)

Os jogos de mãos são "jogos tradicionais que envolvem sequências de movimentos e batimentos rítmicos com as mãos, acompanhados por parlendas ou cantigas" (BRITO, 2013, p. 72). Escolho essa modalidade de jogo para iniciar o processo de musicalização, por ter observado, ao longo dos anos, que as estudantes não ficam tímidas, por não ter movimento corporal expressivo e pelo fato de que o desafio motor com as mãos deixa o canto em segundo plano.

Dessa forma, elas não se preocupam com o cantar, por isso, o pré-conceito de acharem que não têm competência para isso fica em segundo plano, emergindo a voz cantada com alegria e sem desconfortos. Além de ser uma ótima oportunidade para perceberem elementos da música como a melodia, o ritmo e o pulso. 


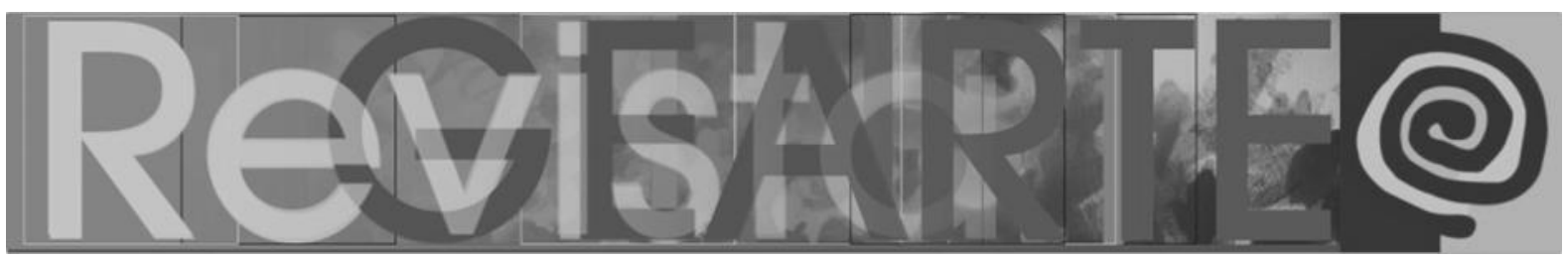

Chamamos pulso da música, à rede constituída pelos tempos ou pulsações regulares sobre a qual se desenvolve e dá vida ao ritmo. Para a criança, diremos que é a batida do coração da música. Também comparamos o pulso ao tic-tac do relógio. Coração e relógio, são para a criança, sinônimos de movimento e vida, atributos - por outro lado essenciais do ritmo musical. (GAINZA, 2009, p. 70, tradução nossa ${ }^{14}$ )

É comum as meninas acelerarem bastante o andamento da música enquanto brincam, ou seja, o jogo de mãos começa lento e termina muito rápido. Isso se dá com qualquer faixa etária, não é um problema, mas, sim, algo que vai sendo trabalhado enquanto se brinca. Esclareço que, quando se aumenta o andamento da música, está se acelerando o pulso.

Nos jogos de mãos, produzimos sons ao percutir - bater - as mãos, as mãos nas pernas, ao estalar dedos ou bater os pés no chão. Ao produzir sons com o próprio corpo, estamos fazendo percussão corporal. Ao desenvolver habilidades em produzir ritmos com o corpo por meio da percussão corporal, as futuras educadoras têm mais um aliado, além da própria voz, para fazer música com seus alunos.

A partir de Borboletinha, diferentes jogos de mãos são aprendidos. Também, novos jogos são criados com canções ou parlendas que elas conhecem, como a canção O Trem de Ferro - somente para citar um exemplo.

De acordo com as necessidades e possibilidades de cada turma do curso de Pedagogia, escolho os modos de conduzir as brincadeiras, quais modalidades vamos fazer e em quais delas vamos nos aprofundar, mas, de modo geral, brincamos com rodas cantadas, jogos de $\operatorname{copos}^{15}$, rodas com nomes ${ }^{16}$, jogos de versos, além dos jogos de mãos, citados anteriormente, e canções.

Gostaria de deixar registrado neste texto mais duas brincadeiras realizadas nas aulas da Pedagogia: A roda cantada portuguesa Indo Eu e o jogo de versos tradicional brasileiro Sereia. 


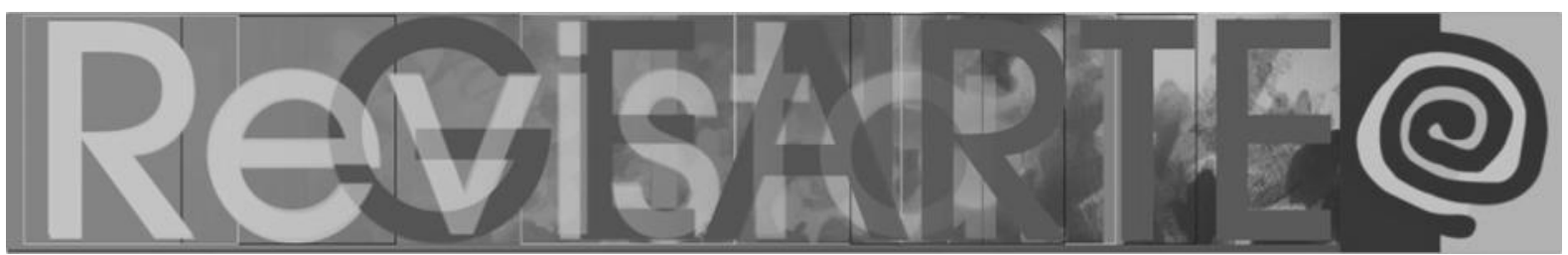

Figura 3 - Indo Eu

Indo eu

Transcrição: Monique Traverzim

Brincadeira de Roda portuguesa

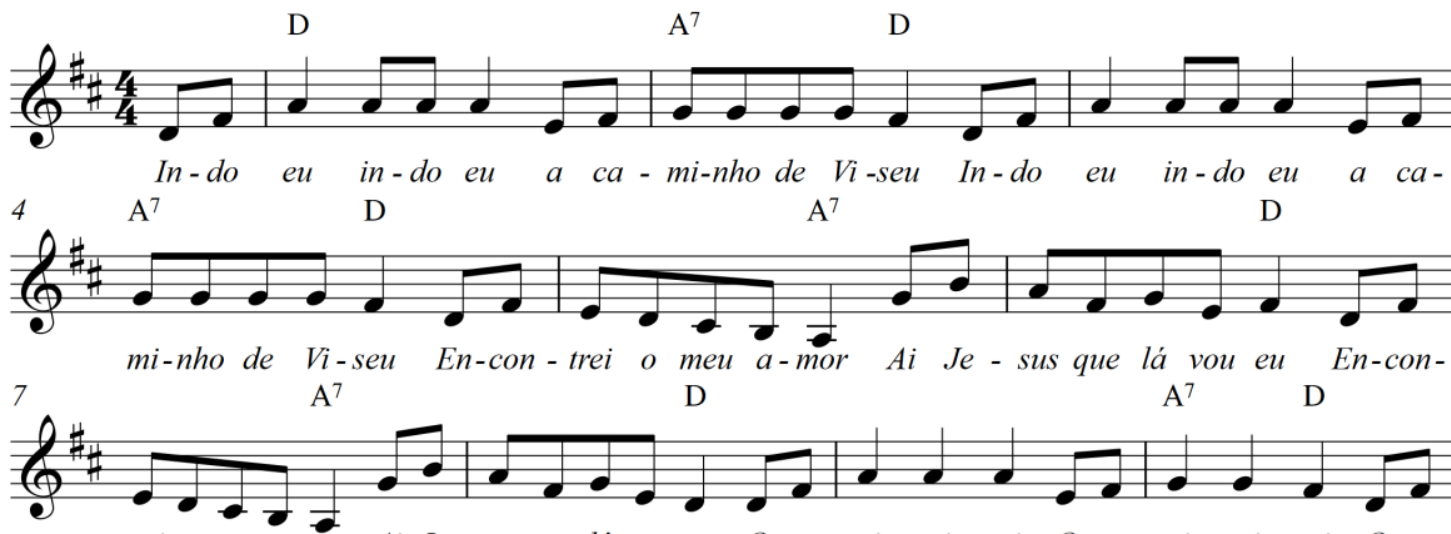

trei o meu a-mor Ai Je-sus que lá vou eu O-ra zuiz truiz truiz O-ra zaiz traiz traiz O-ra 11

$\mathrm{A}^{7} \quad \mathrm{D}$

$\mathrm{A}^{7}$
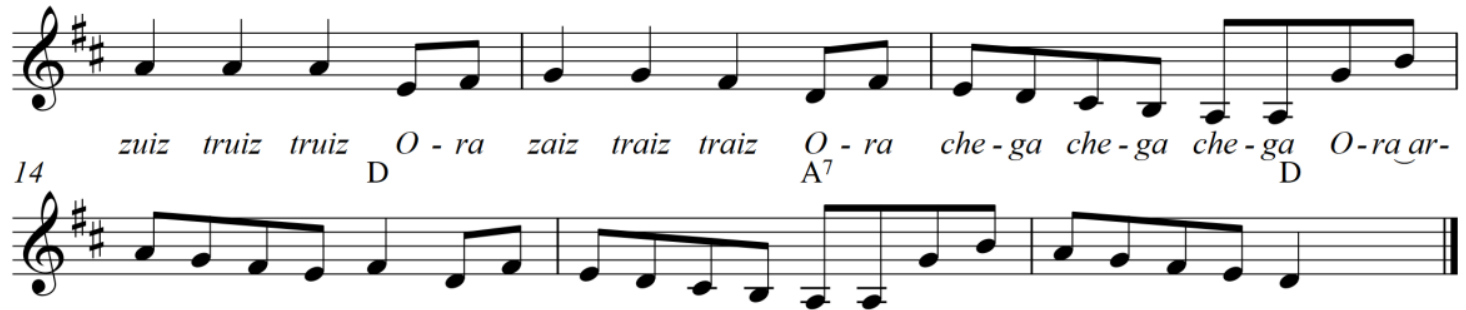

re - da pa-raga trás O-ra che-ga che-ga che-ga O-ra_ar-re-da pa-ra trás.

Editoração: Monique Traverzim

Fonte: Elaborado pela autora (2021).

A roda cantada, também conhecida por brincadeira de roda e cantiga de roda, é uma brincadeira realizada em círculo, em que, geralmente, dá-se as mãos, deslocando-se no espaço para uma ou para outra direção enquanto se canta uma música em uníssono ou dialogada e que pode, também, conduzir uma ação coreográfica (GARCIA, 2001, p. 13). Formamos uma roda para brincar de Indo Eu e todos andam enquanto cantam a primeira parte da letra: "Indo eu, indo eu a caminho de Viseu".

Quando chega na parte ora zuiz truiz truiz, cada um bate palmas das mãos, ora com a pessoa ao lado, ora com a pessoa do outro lado. Quando chega na parte 'ora chega, chega, chega', todos, de mãos dadas, se juntam no centro da roda e depois se afastam, conforme sugere a música. (BAUMGRATZ, 2004, p. 46) 


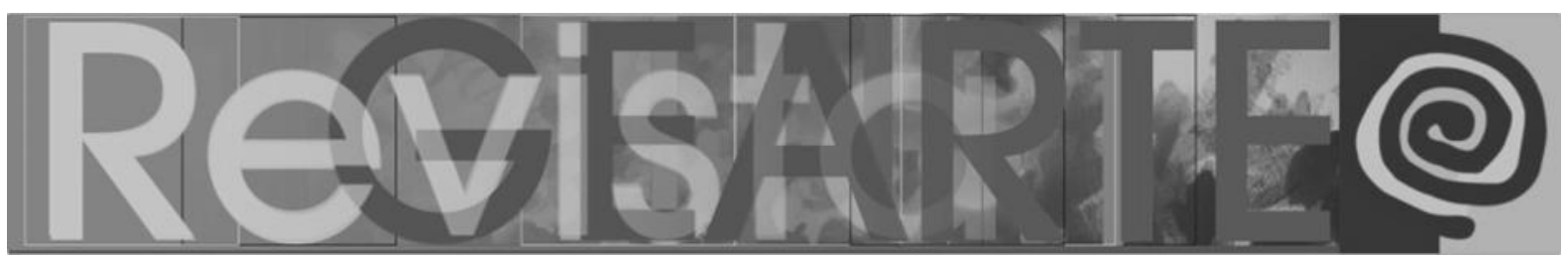

Depois que a turma aprendeu a brincadeira de roda, conversamos sobre sua letra e o significado de Viseu. Quando tenho alunos com descendência portuguesa, logo percebe-se a familiaridade com o português de Portugal ao ouvir a sonoridade dos termos zuiz truiz truiz e zaiz traiz traiz.

Viseu é uma cidade de Portugal. Poucas das alunas têm conhecimento dessa cidade, portanto, para além dos conteúdos musicais presente nessa brincadeira, elas têm a oportunidade de estudar um pouco acerca da cultura portuguesa, que é uma das bases formativas de nossa música. Fala-se muito da miscigenação e do sincretismo da cultura brasileira, mas pouco se reflete sobre eles. É importante buscar entender a identidade brasileira com espírito investigador (ALMEIDA; PUCCI, 2002).

\begin{abstract}
Nesse sentido, é preciso que ouçamos a música das etnias formadoras do ethos brasileiro, que procuremos olhar cuidadosamente para as suas particularidades, é preciso que cantemos sua música, que façamos um esforço para tocá-la, conhecendo de perto seus instrumentos, um pouco dos seus hábitos e artes em geral. Isso tudo pode ser muito mais rico do que simplesmente falar sobre a influência dessas etnias, sem conseguir detectar onde ela se encontra. (ALMEIDA; PUCCI, 2002, p. 21)
\end{abstract}

Ao brincar de roda, é possível experienciar diversos elementos constituintes da música, uma vez que andamos no pulso, fazemos o ritmo da canção ao bater as mãos com as mãos da colega e cantamos a melodia, simultaneamente. Ao cantar, trabalha-se a afinação e a tessitura vocal livre de pressões e tensões, pois o brincar é despretensioso e traz liberdade de cantar sem preocupações técnicas para com essa atividade.

Ressalto que a voz é instrumento carregado de afetividade, fato que já justifica a importância de a pedagoga cantar para seus alunos. Uma mãe canta para seu bebê a fim de acalmá-lo, animá-lo ou mesmo para dialogar com ele. Por que, então, uma professora não deveria cantar para seus pequenos nas escolas de Educação Infantil? Insisto, com as futuras pedagogas, que o saber cantar vem com a prática e que as brincadeiras infantis são um ótimo meio para isso. 


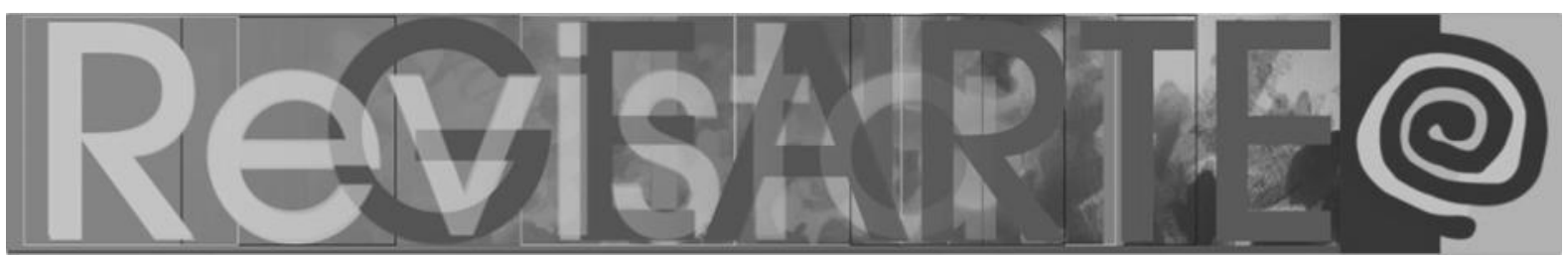

Para além das questões expostas, tem-se, também, os aspectos de desenvolvimento humano trabalhado durante as brincadeiras. No caso específico da brincadeira de roda Indo $E u$, as estudantes ficam encantadas em analisar essa brincadeira e apontar aspectos do desenvolvimento infantil como: sociabilidade, lateralidade, motricidade e ampliação do vocabulário - somente para apresentar alguns dos exemplos que as meninas resgatam de seus estudos no curso de Pedagogia.

Brincadeiras de diferentes culturas, como a indígena e a africana são trabalhadas, além daquelas trazidas ao Brasil por imigrantes japoneses, italianos e franceses. Levo para a sala de aula materiais que conheci em cursos que participei e em pesquisas que fiz em livros e CDs trazidos de outros países. Nessas situações, ensino as brincadeiras e faço os devidos créditos a quem me ensinou ou, ainda, apresento a referência do material, que as estudantes aprendem por meio da experiência.

A pedagoga interessada nesse tipo de repertório pode consultar o livro com CD Rodas e Brincadeiras Cantadas (BAUMGRATZ, 2004) que contém, inclusive, a brincadeiras Indo Eu e o CD Girafulô: Cirandas - Cantigas de roda. "Girafulô é o registro fonográfico das músicas cantadas no projeto de arte-educação 'Cirandas e Mandalas' que contêm oficinas de arte, espetáculo teatral e shows" (TAL CIA DE TRABALHO, 2002, encarte). Com esse material, professoras e seus alunos podem ter contato com sonoridades de diferentes culturas, com os timbres dos instrumentos utilizados na música tradicional brasileira, com os diferentes usos do timbre da voz, melodias e harmonias e músicas arranjadas para o canto coral somente para apontar parte da riqueza sonoro-musical advinda da diversidade cultural. 


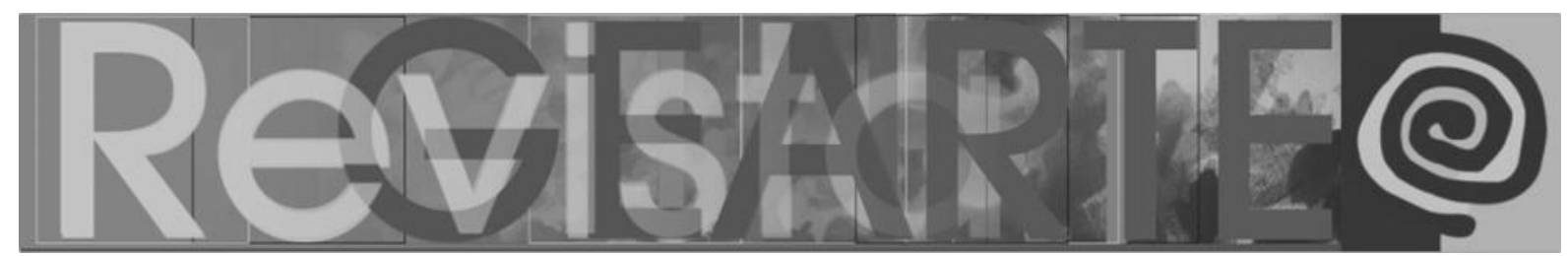

Figura 4 - Sereia

Sereia

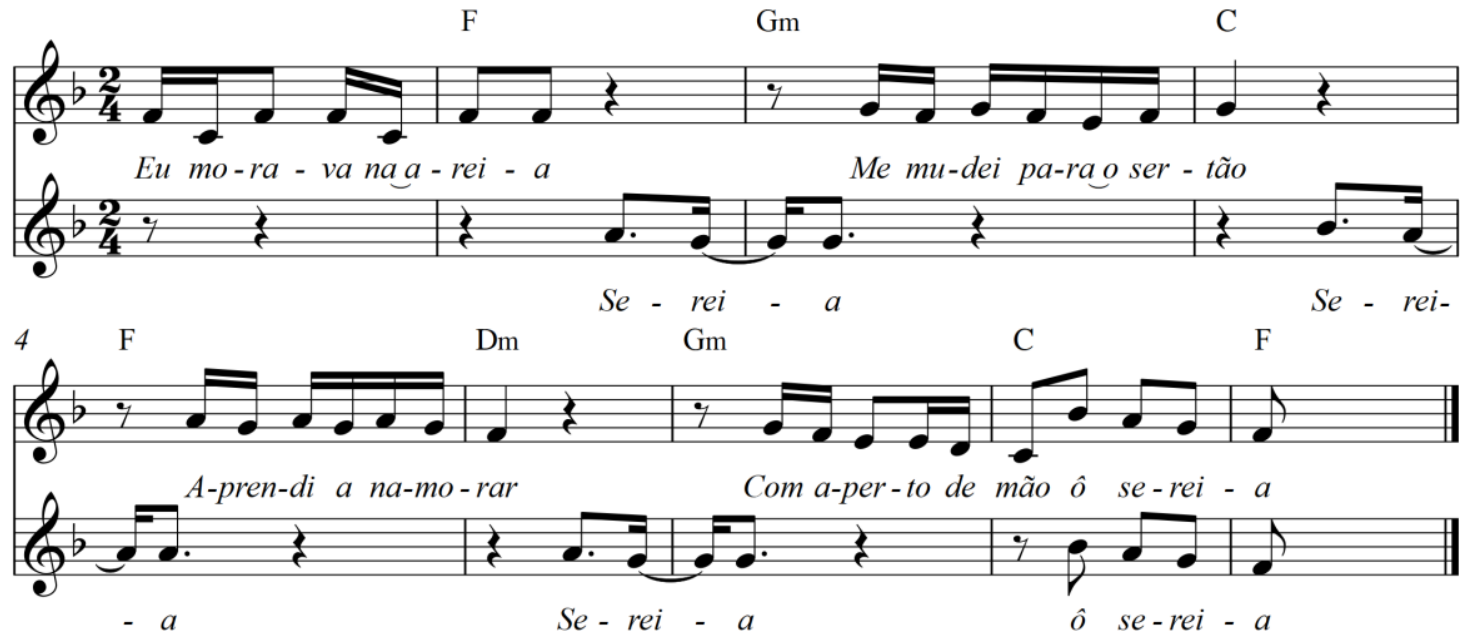

Editoração: Monique Traverzim

Fonte: Partitura musical da roda de verso da cultura brasileira "Sereia" transcrita por Beineke (2006).

O jogo de verso ou roda de verso são "rodas que alternam um refrão com estrofes, nas quais um(a) solista 'joga versos' que podem ser improvisados, adaptados, repetidos etc." (BRITO, 2013, p. 73). Para o desenvolvimento da brincadeira Sereia, as futuras pedagogas aprenderam, primeiramente, a música e um verso da cultura tradicional brasileira, do Rio de Janeiro (SILVA, 2002), para jogar:

\author{
Meu Pai Chama-Se Caco \\ Minha Mãe Caca Maria \\ Lá Em Casa Tudo É Caco \\ Sou Filho Da Cacaria (SILVA, 2002, n.p)
}

Esse verso tem o formato de uma quadrinha, que é

[...] uma das mais antigas e conhecidas formas de poesia folclórica [que até hoje] mantém suas características tradicionais: estrofes de quatro versos setessilábicos, esquema rimático $\mathrm{ABCB}$. Seu conteúdo singelo e a facilidade de assimilação a tornam preferida nas cantigas infantis. (CASCUDO, 2002, p. 548) 


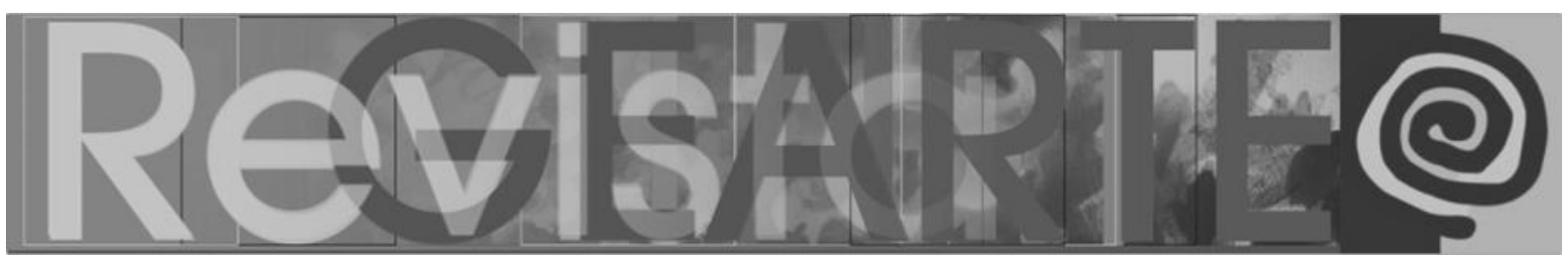

$\mathrm{Na}$ roda de verso, a letra do refrão é trocada pela letra de um verso improvisado. Durante as aulas de musicalização, inicialmente, jogamos com a letra da quadrinha aprendida, todas juntas. Depois, pequenos grupos de alunas sorteiam um novo verso de uma caixinha que preparo com diversas quadrinhas da cultura brasileira, por exemplo: um grupo canta Meu pai chama-se Caco e a outra parte do grupo responde Sereia e, assim, sucede-se, até ao final da música.

Além dos aspectos musicais expostos, anteriormente, nessa brincadeira, as estudantes precisam encaixar a letra da música dentro da métrica da canção, na qual a acentuação das palavras coincide com os acentos fortes e fracos da música, trabalhando-se com a prosódia. Outro ponto a ser destacado é a sonoridade da rima presente nas quadrinhas, que pode ser trabalhada desde a fase da Educação Infantil, especialmente, ao se trabalhar com a criação de novos versos.

Após jogarem com os versos da cultura brasileira, as alunas têm a oportunidade de criar suas próprias quadrinhas. Apresento, aqui, uma criação de um grupo de umas das turmas da Pedagogia:

\title{
Eu estudo na FACCAMP \\ Estou na Graduação \\ Estudo Pedagogia \\ E eu gosto de montão
}

Apresento, também, uma criação coletiva de crianças na faixa etária de quatro anos, na ocasião do Dia das Mães:

\author{
Mamãe eu te amo \\ Você tem brinco e colar \\ Você é amiga e linda \\ E eu quero te beijar
}

Depois de brincar com o repertório da cultura infantil que levo para a turma, algumas das brincadeiras são selecionadas e novas formas de brincar são criadas, por meio da utilização de novos movimentos corporais, de novos gestos e de novos ritmos realizados com percussão corporal ou com copos. Outras brincadeiras são escolhidas e, com elas, são criados arranjos ${ }^{17}$ musicais, por meio do uso de 


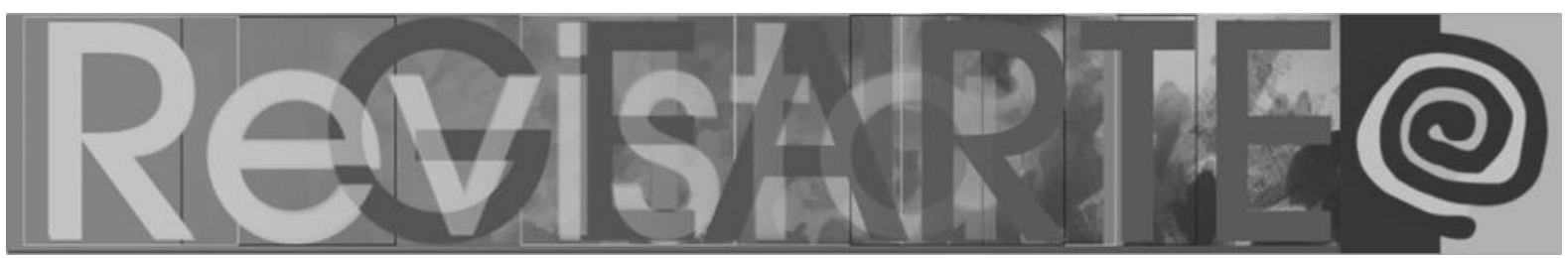

instrumentos de pequena percussão, levados por mim, e, também, construídos pelas alunas. Os instrumentos de pequena percussão são instrumentos de bater, sacudir ou raspar, como o tambor, o reco-reco e o chocalho.

Ao criar um arranjo musical, o indivíduo utiliza de diferentes habilidades musicais, pois precisa combinar timbres dos instrumentos ou dos sons produzidos pelo próprio corpo, criar padrões rítmicos, "escolher quais partes da música serão repetidas, quais instrumentos musicais serão utilizados e em que momentos serão tocados, somente para citar algumas situações da prática de arranjo" (TRAVERZIM, 2015, p. 101).

Espero que, com esse breve relato de três brincadeiras trabalhadas no curso de Pedagogia da UNIFACCAMP, juntamente com a apresentação de um pequeno referencial bibliográfico e fonográfico, as pedagogas em processo formativo e aquelas que já atuam nas escolas de Educação Infantil, possam encontrar inspiração para desenvolverem seus próprios trabalhos de musicalização a favor do desenvolvimento pleno das crianças.

\section{Notas}

1 Optei por usar o termo alunas pela grande maioria das estudantes do curso de Pedagogia serem do sexo feminino. Em oito anos de trabalho nesse curso, tive uma turma com dois alunos do sexo masculino e três turmas com apenas um. Ressalta-se que as classes tinham uma média de oitenta alunos e chegaram até noventa e sete, mas que, com o passar do tempo, foram diminuindo, em especial com a queda do FIES - programa de financiamento estudantil do Governo Federal. Notei, também, por meio de observação do cotidiano na UNIFACCAMP, que após a abertura de turma em uma cidade vizinha à Campo Limpo Paulista e de turmas em EAD, a queda de alunos foi abrupta.

2 Fico, em média, com dez horas/aula da disciplina para trabalhar com musicalização.

3 Foi explicado às futuras pedagogas que a melodia é "o que se organiza a partir das alturas e resulta no que se canta" nas brincadeiras (TRAVERZIM, 2015, p. 92). "Melodia é a sucessão temporal de sons e silêncios, com sentido e direcionalidade" (SEKEFF, 2007, p. 45).

4 O leitor interessado pode buscar o livro Dialética do Esclarecimento: Fragmentos Filosóficos, de Adorno e Horkheimer, para conhecer um pouco mais a respeito do conceito de indústria cultural - um modo de produção de bens culturais hegemônico que se inicia no capitalismo tardio. De acordo com Aguiar (1989), o processo de padronização da música, pela indústria cultural, descarta a necessidade de compreensão musical. "A crítica é trocada pela passividade, pela evasão e pelos reflexos condicionados. A música trocou o ouvinte pelo consumidor, convertendo-se em mercadoria" (op. cit., p. 13).

5 "A tessitura é a quantidade de notas, dentro da extensão vocal, que o indivíduo consegue cantar com qualidade e conforto" (RHEINBOLDT, 2014, p. 7). 


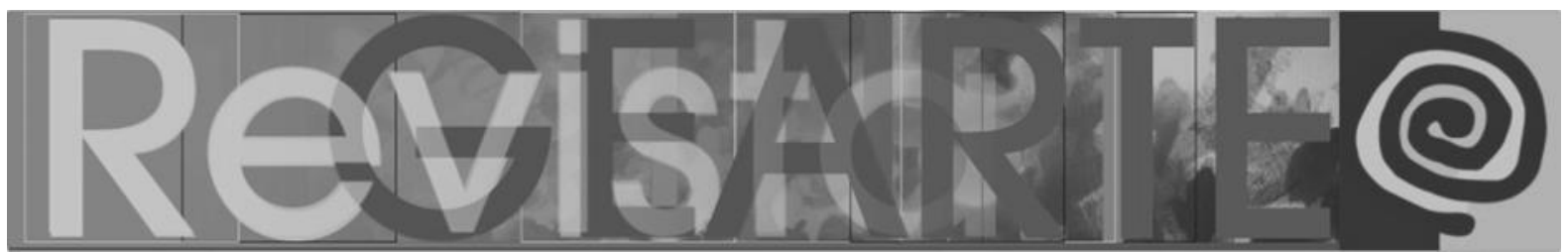

$6 \quad$ "A extensão vocal é a totalidade de notas que uma pessoa consegue emitir, desde a mais grave até a mais aguda" (RHEINBOLDT, 2014, p. 7).

7 "An early exposure to music contributes to the development of music aptitud in children. This is why the quality of the enviroment in wich children are nurtred in their early years is extremely importante. What matters is not the quality os musical stimuli, but rather the quality, wich is determined by the characteristics of the music children listen to and, no less important, to the modality of this exposure" (GORDON; APOSTOLI, 2004, p. 3).

8 "Qualidade característica de um som, timbre é cor, cor musical, propriedade que possibilita a distinção entre sons da mesma altura emitidos por instrumentos diferentes" (SEKEFF, 2007, p. 48). Por meio do timbre podemos reconhecer, por exemplo, a voz de um amigo e o som de um instrumento musical.

9 Lívia, aluna que cursou a disciplina no primeiro semestre de 2019. Na ocasião ela já era formada em Letras e ministrava aulas de inglês no Ensino Fundamental I. Lívia é um pseudônimo criado para que não seja revelada a identidade da aluna.

10 A aluna, também, faz parte da turma de 2019. Não compartilho o semestre que elas cursavam, pois a IES segue o regime de matrícula por disciplinas e temos alunos de diferentes semestres do curso de Pedagogia em uma mesma turma.

11 Optei por usar o termo cultura tradicional da infância no lugar do termo folclore pelo seu desgaste semântico. De acordo com Ikeda (2013, Apud TRAVERZIM, 2015, p. 21) "[...] um dos motivos dessa deterioração se deu pela maneira como os fatos culturais, populares, tradicionais, foram concebidos, estudados e divulgados por muitos folcloristas: de modo descontextualizado, considerados em apenas aspectos fragmentados das expressões em si, nas suas exterioridades e formas, independentemente das suas funções e sentidos profundos para as pessoas e comunidades onde se preservam".

12 "[...] un tipo de alimento auditivo-espiritual completo, denso, pero al mismo tiempo inocuo, como la leche materna, capaz de preparar al oído y la sensibilidad toda, para futuras adquisiciones y para una etapa de madurez. [...] Del mismo modo que la leche materna, la presencia de materiales folklóricos musicales en la educación atenuará el efecto contraproducente de otros materiales más pobres e inadecuados" (GAINZA, 2010, p. 32).

13 "El folklore infantil es fácil de captar, claro y sin rebuscamentos. Atrae al oído por su ritmo pitoresco, por la juguetona ingenuidad de sus textos. Mueve elementos primitivos básicos, sobre todo en relación a lo corporal y afectivo, lo cual lo aproxima al hombre sencillo y por lo tanto a los niños. Desde al punto de vista musical, se desarrolla sobre elementos claramente delimitados que constituyen su sistema melódico, armónico o rítmico. A causa de su simplicidad resulta en un vehículo apto para la expresión de sentimientos e ideas elementales concretas" (GAINZA, 2010, p. 32).

14 "Llamamos pulso de la música a la red constituída por los tiempos o pulsaciones regulares sobre la cual se desenvuelve y cobra vida el ritmo. Al niño le diremos que es el latido de la música. También comparamos el pulso com el tic-tac del reloj. Corazón y reloj son para el niño sinónimos de movimento y de vida, atributos -por otra parte- essenciales del ritmo musical". (GAINZA, 2009, p. 70)

15 São cantigas de jogo da cultura da infância, que, originalmente, eram brincadas passando-se um objeto enquanto se cantava uma canção.

16 "Rodas cantadas nas quais se destacam os nomes dos participantes. Geralmente tais rodas também são rodas de escolha, posto que convidam um a um dos participantes a entrar na roda, dar um abraço, trocar de papeis etc." (BRITO, 2013, p. 73).

17 "Fazer um arranjo implica organizar o modo de execução de uma obra musical" (BRITO, 2003, p. 173). 


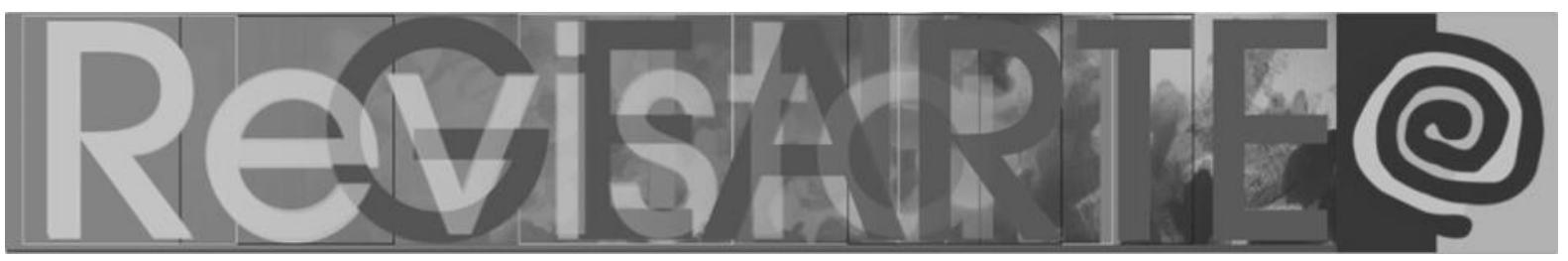

\section{Referências}

ABRA A RODA TIN DÔ LÊ LÊ [Compositor e intérprete]: Lydia Hortélio. São Paulo: Brincante Produções Artísticas Ltda, 2020. 1 CD.

ADORNO, Theodor W. \& HORKHEIMER, Max. Dialética do Esclarecimento: Fragmentos filosóficos. Trad.: Guido Antonio de Almeida. Rio de Janeiro: Zahar, 1986.

AGUIAR, Joaquim Alves de. Música popular e indústria cultural. 1989. 196f. Dissertação (Mestrado) - Universidade Estadual de Campinas, Instituto de Estudos da Linguagem. Campinas, SP: 1989. Disponível em: <http://www.repositorio.unicamp.br/handle/REPOSIP/269567>. Acesso em: 13 jul. 2018.

ALMEIDA, M. Berenice de; PUCCI, Magda D. Outras terras, outros sons. São Paulo: Callis, 2002.

AZEVEDO, Heloisa Helena Oliveira de. Educação infantil e formação de professores: para além da separação cuidar-educar. São Paulo: Editora Unesp, 2013.

BAUMGRATZ, Jacqueline (org.). Rodas e Brincadeiras cantadas. São José dos Campos: Gráfica Modelo, 2004. 1 CD.

BEINEKE, Viviane. Música na Educação Infantil: propostas para a formação integral da criança. São Paulo: Peirópolis, 2003.

BEINEKE, Viviane. Lenga La lenga: jogos de mão e copos. São Paulo: Ciranda Cultural Editora e Distribuidora Ltda., 2006.

BRITO, Teca Alencar de. De roda em roda: brincando e cantando o Brasil. São Paulo: Peirópolis, 2013. 1 CD.

CASCUDO, Luís da Câmara. Dicionário do folclore brasileiro. 11. ed. São Paulo: Global, 2002 [1999].

CASTANHO, Marisa Irene Siqueira. Psicologia da educação e ensino de música: contribuições de Vygotsky. In: LIMA, Sonia Regina Albano (org.). Ensino, Música e Interdisciplinaridade. 4. ed. São Paulo: BT Acadêmica, 2019. p. 265-292.

CORREA, Aruna Noal. Não há como estar em uma sala de aula de educação infantil sem brincar sonoramente com as crianças: a formação musical e pedagógico-musical de professores. In: BELLOCHIO, Cláudia Ribeiro; GARBOSA, Luciane W. F. Educação musical e pedagogia: pesquisas, escutas e ações. Campinas: Mercado de Letras, 2014.

FERREIRA, Aurélio B. de H. Novo Dicionário Eletrônico Aurélio. 4. ed. versão eletrônica 6.1. Curitiba: Editora Positivo, 2008.

GAINZA, Violeta Hemsy de. Fundamentos, materiales y otras técnicas de la educación musical. Buenos Aires: Melos, 2010.

GAINZA, Violeta Hemsy de. La iniciación musical del niño. 1. ed. 1. reimp. Buenos Aires: Melos Ediciones Musicales S.A., 2009.

GARCIA, Rose Marie Reis. Brincadeiras cantadas. Porto Alegre: Kuarup, 2001.

GIGA, Idalete. A educação vocal da criança. Música, Psicologia e Educação, Porto, n. 6, p. 69-80, 2004. Disponível em: <http://hdl.handle.net/10400.22/3153>. Acesso em: 20 abr. 2020.

GIRAFULÔ: Cirandas - Cantigas de Roda. Compositores: Bia Bedran; Toré; José Neto; Tomiake. São Paulo: MCD World Music, 2002. 1CD.

GORDON, Edwin E. Teoria de aprendizagem musical para recém-nascidos e crianças em idade pré-escolar. Trad.: Paulo Maria Rodrigues e Victor Gaspar. 3. ed. rev. e atualizada. Lisboa: Fundação Calouste Gulbenkian, 2000. 


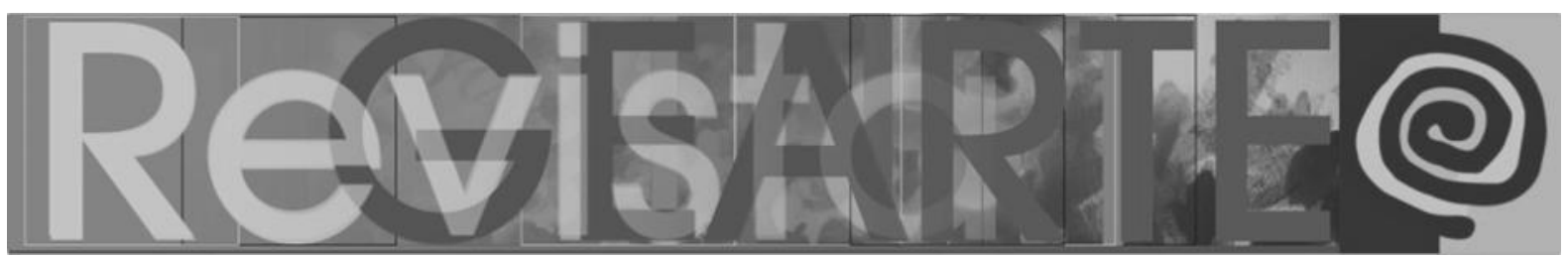

GORDON, Edwin E. and APOSTOLI, Andrea. Songs and Chants without Words according to the principles of Music Learning Education. Chicago: GIA Publications, INC., 2015.

LARROSA BONDIA, Jorge. Notas sobre a experiência e o saber de experiência. Revista Brasileira de Educação, Rio de Janeiro, n. 19, p. 20-28, abr. 2002. Disponível em: $<$ http://www.scielo.br/scielo.php?script=sci_arttext\&pid=\$1413-24782002000100003\&lng=en\&nrm =iso $>$. Acesso em> 25 abr. 2020.

RHEINBOLDT, Juliana Melleiro. Preparo vocal para coro infantil: análise, descrição e relato da proposta do maestro Henry Leck aplicada ao "Coral da Gente" do Instituto Baccarell. Dissertação (Mestrado) - Universidade Estadual de Campinas, Instituto de Artes. Campinas: 2014. Disponível em: <http://www.repositorio.unicamp.br/handle/REPOSIP/285244>. Acesso em: 20 abr. 2020.

RODRIGUES, Helena; RODRIGUES Paulo Maria. Arte de ser professor: o projecto musical e formativo grande bichofonia. Lisboa: Edições Colibri, 2014.

SÃO PAULO (Estado). Lei Complementar no 1.146, cria a Aglomeração Urbana de Jundiaí-AUJundiaí, e dá providências correlatas. São Paulo, 24 de agosto de 2011. Disponível em: $<$ https://www.al.sp.gov.br/repositorio/legislacao/lei.complementar/2011/lei.complementar-114624.08.2011 >. Acesso em: 01. abr. 2020.

SCHAFER, R. Murray. O ouvido pensante. Trad.: Marisa Trench de Oliveira Fonterrada, Magda R. G. da Silva, Maria Lúcia Pascoal. São Paulo: Editora UNESP, 1991.

SEKEFF, Maria de Lourdes. Da música, seus usos e recursos. 2. ed. rev. amp. São Paulo: Editora UNESP, 2007.

SILVA, Salatiel. Ciranda de Cantigas: parlendas, quadras, quadras-adivinhas. Sorocaba: Ciranda Cultural, 2002.

SOBREIRA, Silvia e BOECHAT, Bruno. A extensão vocal infantil. In: XXII Congresso Nacional da Associação Brasileira de Educação Musical, 2015, Natal. Anais [...]. Educação Musical: formação humana, ética e produção do conhecimento. Natal: ABEM. s/p. Disponível em: <http://abemeducacaomusical.com.br/conferencias/index.php/xxiicongresso/xxiicongresso/paper/v iewFile/1024/421 >. Acesso em: 22 abr. 2020.

TRAVERZIM, Monique. A brincadeira da cultura tradicional da infância na formação musical do pedagogo. Dissertação (Mestrado em Música) - Universidade Estadual Paulista, Instituto de Artes. São Paulo: 2015. Disponível em: <http://hdl.handle.net/11449/136661>. Acesso em 22 abr 2020.

\section{Monique Traverzim}

Professora nos cursos de Licenciatura em Música e Pedagogia do Centro Universitário Campo Limpo Paulista UNIFACCAMP/SP e no programa Sopro Novo Yamaha de iniciação musical. Flautista no Duo RaZim. Bacharel em Música, Mestre e Doutoranda na Universidade Estadual Paulista. Especialista em Educação Musical pela Faculdade de Música Carlos Gomes. Membro do Grupo de Pesquisa em Educação Musical G-PEM/IA/UNESP e no de Arte/Educação (GPAE/UNIFACCAMP).

ORCID: https://orcid.org/0000-0001-9720-2765

E-mail: niqueflauta@gmail.com

Currículo: http://lattes.cnpq.br/9875191150111971

Recebido em 22 de fevereiro de 2021 Aceito em 27 de abril de 2021 